\title{
SIEDLISKOWE UWARUNKOWANIA WYSTĘPOWANIA WĄTROBOWCA FRULLANIA DILATATA W WIGIERSKIM PARKU NARODOWYM (PÓŁNOCNO-WSCHODNIA POLSKA)
}

\author{
HABITAT CHARACTERISTICS WHICH DETERMINE LIVERWORT FRULLANIA \\ DILATATA OCCURRENCE IN THE WIGRY NATIONAL PARK \\ (NORTH-EASTERN POLAND)
}

\author{
Piotr GóRski, Maciej Romański, Dominik Tomaszewski
}

\begin{abstract}
P. Górski, Katedra Botaniki, Uniwersytet Przyrodniczy w Poznaniu, ul. Wojska Polskiego 71 C, 60-625 Poznań, Poland, e-mail: piotr.gorski@up.poznan.pl

M. Romański, Wigierski Park Narodowy, Krzywe 82, 16-402 Suwałki, Poland, e-mail: maciej.romanski@wigry.org.pl

D. Tomaszewski, Instytut Dendrologii Polskiej Akademii Nauk, ul. Parkowa 5, 62-035 Kórnik, Poland, e-mail: dominito@man.poznan.pl
\end{abstract}

\begin{abstract}
Aвstract. The aim of the article was to verify the hypothesis that humidity, temperature and light conditions play a fundamental role in the distribution of Frullania dilatata within the forest complexes in the Wigry National Park. 41 monitoring localities were selected in places of epiphytic liverworts occurrence (22 sites with F. dilatata, 19 - without these plant). Humidity and temperature were recorded hourly during one year. Light conditions on the tested sites were determined on the basis of hemispherical photos. Additional parameters were calculated based on the digital terrain model in the SagaGis program. The results indicate that the hypothesis is false.
\end{abstract}

KEY WORDS: epiphytes, humidity, temperature, Frullania dilatata, Wigry National Park, Poland

\section{WSTĘP}

Wątrobowiec Frullania dilatata (L.) Dumort. (miedzik płaski) jest gatunkiem epifitycznym występującym na terenie całego obszaru Polski (Szweykowski 2006). Obecnie ma status gatunku niezagrożonego w kraju (KLAMA \& GórSKI 2018) oraz Europie (HodgetTS 2015). W ostatnich latach obserwuje się jednak spadek liczby stanowisk omawianego gatunku. Analizę tego zjawiska przeprowadzili ostatnio GóRsKI i RoMAŃSKI (2018). Wskazuje ona, że od lat 70. ubiegłego stulecia utrzymuje się niski (aż o połowę niższy niż w latach 50-60.) poziom notowalności $F$. dilatata. Szczególnie dotyczy to obszarów niżowych, tj. Wielkopolski, Pomorza Zachodniego, Śląska Opolskiego, Mazowsza czy północno-wschodniej Polski (np. Rejment-Grochowska \& Mickiewicz 1962, Rejment GrochowsKa 1964a, b, GocŁaWsKa 1966, Karczmarz
\& SoкоŁowski 1992, 1995, Stebel 1997, 2002, 2008, 2012, FudAli 1999, PISAREK i in. 2002, GórSKI 2006a, b, c, 2007a, b, c, 2010, 2013, ŁACHACZ \& PisareK 2007, FoJcIK i in. 2017). Zjawisko zanikania i rzadkości epifitów i epiksyli jest znane i opisywane od wielu lat w Polsce i Europie, a mszaki wymienionych grup są stale obecne na czerwonych listach gatunków zagrożonych (np. KUBINSKÁ i in. 2001, SCHNYDER i in. 2004, KuČERA $i$ in. 2012, HODGETTS 2015, KlAMA \& GóRSKI 2018). Jedną z wskazywanych przyczyn tego procesu jest gospodarka leśna i związane $z$ nią zmiany mikroklimatu wnętrza lasu (głównie spadek wilgotności) oraz brak odpowiedniego podłoża dla epifitów (obecność starych drzew; SöDERSTRÖM 1988, ANDERSSON \& HytTeborn 1991). Analiza obecnego rozmieszczenia F. dilatata w Polsce pozwala przypuszczać, że populacje występujące w Karpatach, w południowej części kraju są nadal liczne i niezagrożone (Stebel \& ZubeL 
2018). Zaskakujący jest jednak brak tego wątrobowca w niektórych masywach górskich cechujących się wysokim stopniem naturalności, np. w Gorcach (MIERZEŃSKA 1994) czy Górach Kaczawskich (WiLCZYŃSKA 1974). Zasadne więc wydaje się postawienie pytania o rolę mikroklimatu wnętrza lasu w występowaniu tej rośliny. Celem niniejszej pracy jest weryfikacja hipotezy, że wilgotność, temperatura i warunki oświetlenia odgrywają zasadniczą rolę $\mathrm{w}$ rozmieszczeniu F. dilatata w obrębie kompleksów leśnych Wigierskiego Parku Narodowego.

\section{MATERIAŁ I METODY \\ REJESTRACJA ZMIENNYCH \\ MIKROSIEDLISKOWYCH - TEMPERATURA I WILGOTNOŚĆ}

$\mathrm{Na}$ podstawie rozpoznanego rozmieszczenia $F$. dilatata w Wigierskim Parku Narodowym (GóRSKI \& RoMAŃski 2018) wytypowano 41 powierzchni monitoringowych, w których rejestrowano wilgotność i temperaturę $\mathrm{w}$ miejscach występowania epifitów

Tabela 1. Zestawienie podstawowych danych dotyczących instalacji rejestratorów

Table 1. Basic information about installation of data loggers

\begin{tabular}{|c|c|c|c|c|c|}
\hline TH_KOD & Podłoże & WGS_N & WGS_E & $\begin{array}{c}\text { Lokalizacja } \\
\text { Location }\end{array}$ & Wydz. \\
\hline \multicolumn{6}{|c|}{ Stanowiska z (localities with) Frullania dilatata } \\
\hline TH-08 & Corylus avellana & 54.061803 & 23.056461 & Leszczewek & $118 \mathrm{~d}$ \\
\hline TH-10 & Fraxinus excelsior & 54.061955 & 23.054010 & Leszczewek & $118 \mathrm{f}$ \\
\hline TH-11 & Corylus avellana & 54.055560 & 23.057429 & Roklas & $120 \mathrm{f}$ \\
\hline $\mathrm{TH}-13$ & Corylus avellana & 54.061854 & 23.057449 & Leszczewek & $118 \mathrm{~d}$ \\
\hline $\mathrm{TH}-21$ & Populus tremula & 54.063006 & 23.054189 & Leszczewek & 1071 \\
\hline TH-22 & Populus tremula & 54.062802 & 23.054004 & Leszczewek & 1071 \\
\hline TH-23 & Acer platanoides & 54.062778 & 23.053852 & Leszczewek & 1071 \\
\hline TH-24 & Corylus avellana & 54.061982 & 23.056755 & Leszczewek & $118 \mathrm{~d}$ \\
\hline TH-25 & Quercus robur & 54.062216 & 23.054985 & Leszczewek & $118 \mathrm{~d}$ \\
\hline TH-26 & Corylus avellana & 54.062708 & 23.055696 & Leszczewek & $118 \mathrm{~d}$ \\
\hline TH-28 & Fraxinus excelsior & 54.003246 & 23.198738 & Wierchstaw & $361 b$ \\
\hline TH-30 & Corylus avellana & 54.002817 & 23.200024 & Wierchstaw & $361 \mathrm{i}$ \\
\hline TH-31 & Acer platanoides & 54.001062 & 23.202114 & Wierchstaw & $361 j$ \\
\hline TH-32 & Acer platanoides & 54.001808 & 23.199892 & Wierchstaw & $361 j$ \\
\hline TH-33 & Corylus avellana & 54.002129 & 23.202097 & Wierchstaw & $361 j$ \\
\hline TH-34 & Tilia cordata & 54.003645 & 23.199439 & Wierchstaw & $361 d$ \\
\hline TH-35 & Fraxinus excelsior & 54.008161 & 23.037049 & Powały & $383 c$ \\
\hline TH-37 & Acer platanoides & 54.001793 & 23.201556 & Wierchstaw & $361 j$ \\
\hline TH-38 & Populus tremula & 54.001151 & 23.200246 & Wierchstaw & $362 \mathrm{i}$ \\
\hline TH-39 & Populus tremula & 54.071100 & 23.035774 & Sobolewski Gościniec & $81 \mathrm{i}$ \\
\hline TH-40 & Fraxinus excelsior & 54.007061 & 23.040822 & Powały & $382 a$ \\
\hline \multicolumn{6}{|c|}{ Stanowiska bez (localities without) Frullania dilatata } \\
\hline TH-01 & Corylus avellana & 54.047930 & 23.031207 & Sobolewo & $111 \mathrm{k}$ \\
\hline TH-02 & Quercus robur & 54.076396 & 23.012717 & Bindas & $51 \mathrm{c}$ \\
\hline TH-03 & Corylus avellana & 54.048707 & 23.028542 & Sobolewo & $111 \mathrm{f}$ \\
\hline TH-04 & Quercus robur & 54.076659 & 23.011992 & Bindas & $51 \mathrm{c}$ \\
\hline TH-05 & Tilia cordata & 54.076301 & 23.015361 & Bindas & $51 \mathrm{c}$ \\
\hline TH-06 & Tilia cordata & 54.090708 & 23.038526 & Leszczewek & $63 \mathrm{~b}$ \\
\hline TH-07 & Corylus avellana & 54.048840 & 23.029282 & Sobolewo & $111 \mathrm{f}$ \\
\hline $\mathrm{TH}-12$ & Quercus robur & 54.075092 & 23.016179 & Bindas & $51 c$ \\
\hline TH-14 & Acer platanoides & 54.091422 & 23.040553 & Leszczewek & $63 a$ \\
\hline TH-15 & Tilia cordata & 54.090514 & 23.037804 & Leszczewek & $63 \mathrm{~b}$ \\
\hline TH-16 & Carpinus betulus & 54.091503 & 23.038905 & Leszczewek & $63 b$ \\
\hline TH-17 & Quercus robur & 54.088073 & 23.037581 & Leszczewek & $64 a$ \\
\hline TH-18 & Tilia cordata & 54.048326 & 23.030453 & Sobolewo & $111 \mathrm{k}$ \\
\hline TH-19 & Tilia cordata & 54.075510 & 23.016215 & Bindas & $51 \mathrm{c}$ \\
\hline TH-20 & Tilia cordata & 54.048631 & 23.030032 & Sobolewo & $111 \mathrm{k}$ \\
\hline TH-27 & Tilia cordata & 54.097682 & 23.043167 & Kamionka (S) & $61 \mathrm{~g}$ \\
\hline TH-29 & Tilia cordata & 54.097101 & 23.043052 & Kamionka (S) & $61 \mathrm{~h}$ \\
\hline TH-36 & Ulmus campestris & 54.097594 & 23.042559 & Kamionka (S) & $61 \mathrm{~h}$ \\
\hline TH-41 & Tilia cordata & 54.098394 & 23.046202 & Kamionka (N) & $61 \mathrm{k}$ \\
\hline $\mathrm{TH}-42$ & Quercus robur & 54.098537 & 23.045482 & Kamionka (N) & $61 \mathrm{k}$ \\
\hline
\end{tabular}

Objaśnienia: TH_KOD - numer rejestratora temperatury i wilgotności; Podłoże - forofit, na którym instalowano rejestrator; WGS_N, WGS_E - współrzędne geograficzne; Wydz. - numer oddziału i pododdziału na mapie leśnej Wigierskiego PN.

Abbreviations: TH_KOD - name of temperature and humidity data logger; Podłoże - substrate (tree or shrub) on which the data logger was installed; WGS_N, WGS_E - geographical coordinates; Wydz. - subcompartment on the forest map of Wigry National Park. 
(tj. na korze drzew lub krzewów). Badane powierzchnie obejmowały 22 stanowiska z F. dilatata (tu oznaczane jako: Frullania + ) oraz 19 bez tej rośliny (Frullania -), choć występowały tam inne epifity (głównie Metzgeria furcata, por. tab. 1). Dane mikroklimatyczne gromadzono rejestratorem Hobo U23-001 Pro V2 firmy Onset (zintegrowany higrometr i termometr) w odstępach godzinnych przez pełen rok kalendarzowy (od połowy sierpnia 2018 do 2019 r.). Ze względu na błędy odczytu trzech rejestratorów część danych $z$ nich została pominięta.

$\mathrm{Na}$ podstawie pomiarów wilgotności względnej oraz temperatury obliczono zmienne dla każdego dnia: średnią, minimum, maksimum, medianę i amplitudę (różnicę między minimum i maksimum), które służyły następnie do wyliczeń na poziomie miesiąca. Część zmiennych nie spełniała warunku o normalności rozkładu (wykorzystano test Shapiro-Wilka) lub jednorodności wariancji (testy Levene'a, Bowna-Forsythe'a, O'Briena oraz Bartletta), dlatego nie zostały one uwzględnione $\mathrm{w}$ analizie dyskryminacji.

\section{REJESTRACJA ZMIENNYCH MIKROSIEDLISKOWYCH - NASŁONECZNIENIE}

Na wszystkich 41 powierzchniach monitoringowych wykonano zdjęcia hemisferyczne aparatem Canon EOS 50D (z obiektywem Sigma 4,5 mm DC HSM 1:2.8). Uzyskano w ten sposób następujące zmienne dotyczące nasłonecznienia: 1) DSF (direct site factor) - wyraża stosunek bezpośredniego promieniowania słonecznego docierającego do analizowanej powierzchni w odniesieniu do promieniowania, które by dotarło do stanowiska, gdyby nie było nad nim elementów zacieniających („przy czystym niebie”), 2) ISF (indirect site factor) - definiowane podobnie, dotyczy promieniowania rozproszonego. Ponadto $z$ cyfrowego modelu terenu uzyskano kolejne parametry: 3) VisSky (Visible Sky) - procentowy udział widocznego „nieba” nad stanowiskiem badawczym (uzależniony od kształtu powierzchni), 4) Total Inso (Total Insolation) - całkowite promieniowanie, jakie może dotrzeć do danej powierzchni z uwzględnieniem ukształtowania terenu, 5) Direct Ins (Direct Insolation) - definiowane podobnie, $\mathrm{w}$ odniesieniu do promieniowania bezpośredniego, 6) Diffuse In (Diffuse Insolation) definiowane podobnie, $w$ odniesieniu do promieniowania rozproszonego. Zmienne te zostały wyliczone w programie SagaGis dla całego roku, a szczegółowy ich opis znajduje się w następujących opracowaniach: OKe (2000), Wilson i Gallant (2000), Hantzschel i in. (2005), BOEHNER i ANTONIC (2009).

Dane o warunkach oświetlenia $\mathrm{w}$ obu grupach stanowisk porównano testem nieparametrycznym U Manna-Whitneya, ponieważ część zmiennych nie spełniała warunku o normalności rozkładu.
Wszystkie analizy przeprowadzono z wykorzystaniem programu JMP Pro 15 (SAS).

\section{WYNIKI}

\section{ZMIENNOŚĆ TEMPERATURY JAKO CZYNNIK RÓŻNICUJĄCY BADANE GRUPY STANOWISK}

Analizie poddano zmienność temperatury dla dwóch grup stanowisk: 1) grupa 21 stanowisk z F. dilatata (Frullania + ) oraz 2) grupa 19 stanowisk bez tego wątrobowca, ale z innymi epifitami, głównie Metzgeria furcata (Frullania -). Na rycinie 1 przedstawiono podstawowe charakterystyki termiki badanych grup stanowisk w ciągu 12 miesięcy.

W odniesieniu do minimalnej i maksymalnej zarejestrowanej temperatury dziennej oraz wartości średniej dziennej temperatury (ryc. 1A, B, C) badane grupy stanowisk nie różnią się istotnie. Dane te są niemal identyczne w ciągu całego roku. Różnice zauważa się natomiast w odniesieniu do wartości amplitudy dziennej na badanych powierzchniach (ryc. 1D). Stanowiska z F. dilatata cechują się wyższymi wartościami tej zmiennej, czyli zarejestrowane różnice między temperaturą minimalną a maksymalną w ciągu doby są wyższe niż na forofitach typu Frullania -. Lokalizacje $z$ miedzikiem płaskim mają zatem bardziej rozchwianą termikę $\mathrm{w}$ ciągu doby.

\section{WILGOTNOŚĆ JAKO CZYNNIK RÓŻNICUJĄCY BADANE GRUPY STANOWISK}

Wyniki analizy zmienności wilgotności prowadzono dla wymienionych dwóch grup stanowisk (21 z Frullania + oraz 18 z Frullania -). Wartości minimalnej i maksymalnej oraz średniej wilgotności względnej dziennej (ryc. 2A, B, C) są bardzo zbliżone na wszystkich stanowiskach. Podobnie jak w przypadku temperatury różnice zaznaczają się przy analizie amplitudy wilgotności względnej w ciągu dnia (ryc. 2D). Stanowiska z F. dilatata cechują się większymi wahaniami wilgotności w ciągu dnia. Są pod tym względem mniej stabilne $\mathrm{w}$ porównaniu $\mathrm{z}$ lokalizacjami Frullania -.

\section{NASŁONECZNIENIE BADANYCH GRUP STANOWISK}

Wyniki analizy nasłonecznienia prowadzono dla wymienionych wyżej grup stanowisk (Frullania + oraz Frullania -). Wartości tej cechy uzyskano na dwa sposoby. Pierwszy dotyczył pomiaru nasłonecznienia poprzez wykonanie zdjęć hemisferycznych bezpośrednio w terenie, $w$ miejscu instalacji rejestratorów (na badanych 41 stanowiskach obu grup). W drugim przypadku dane uzyskano $z$ cyfrowego modelu terenu na podstawie lokalizacji GPS. 


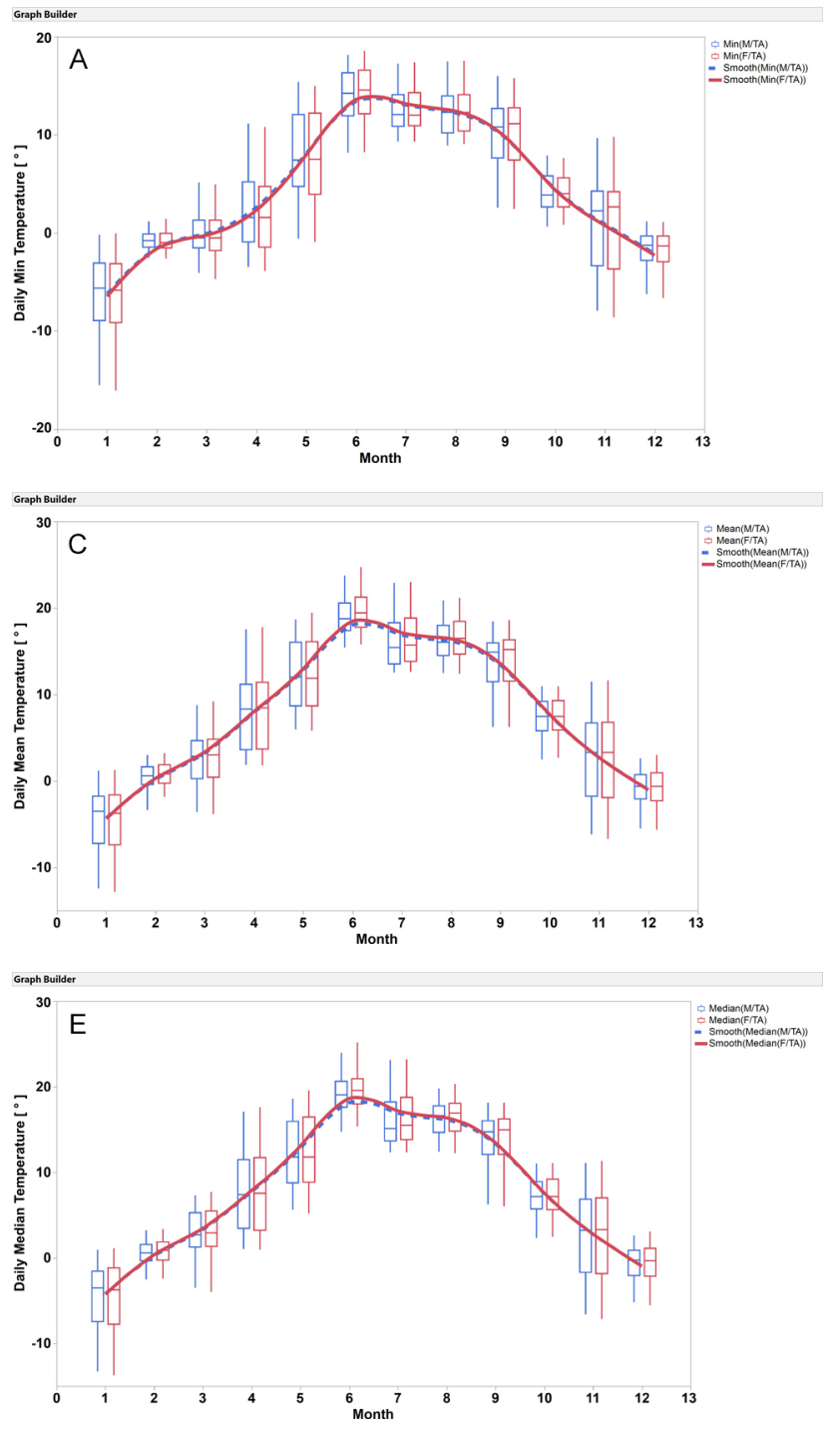

Analizowano sześć parametrów oświetlenia dla obu grup stanowisk (19 z Frullania - i 22 z Frullania + ). Testowano, czy grupy te różnią się znacząco pod względem tych zmiennych, co pośrednio sugerowałoby odpowiedź na pytanie, czy występowanie F. dilatata można powiązać z warunkami oświetlenia w danym miejscu. Stwierdzone różnice są niewielkie i poza przypadkiem parametru Diffuse In nie stwierdzono, by były istotne, a nawet $\mathrm{w}$ przypadku tej zmiennej ich istotność jest na poziomie granicznym (ryc. 3). Można więc wysunąć wniosek, że warunki oświetlenia nie są czynnikiem determinującym występowanie $F$. dilatata na badanym obszarze.

\section{ANALIZA DYSKRYMINACYJNA CZYNNIKÓW RÓŻNICUJĄCYCH BADANE GRUPY STANOWISK}

Na podstawie uzyskanych pomiarów temperatury, wilgotności i nasłonecznienia wyliczono blisko 190 zmiennych mikroklimatycznych. Wykluczono zmienne niespełniające założeń analizy dyskryminacyjnej oraz te dotyczące miesięcy zimowych (listopad-luty).
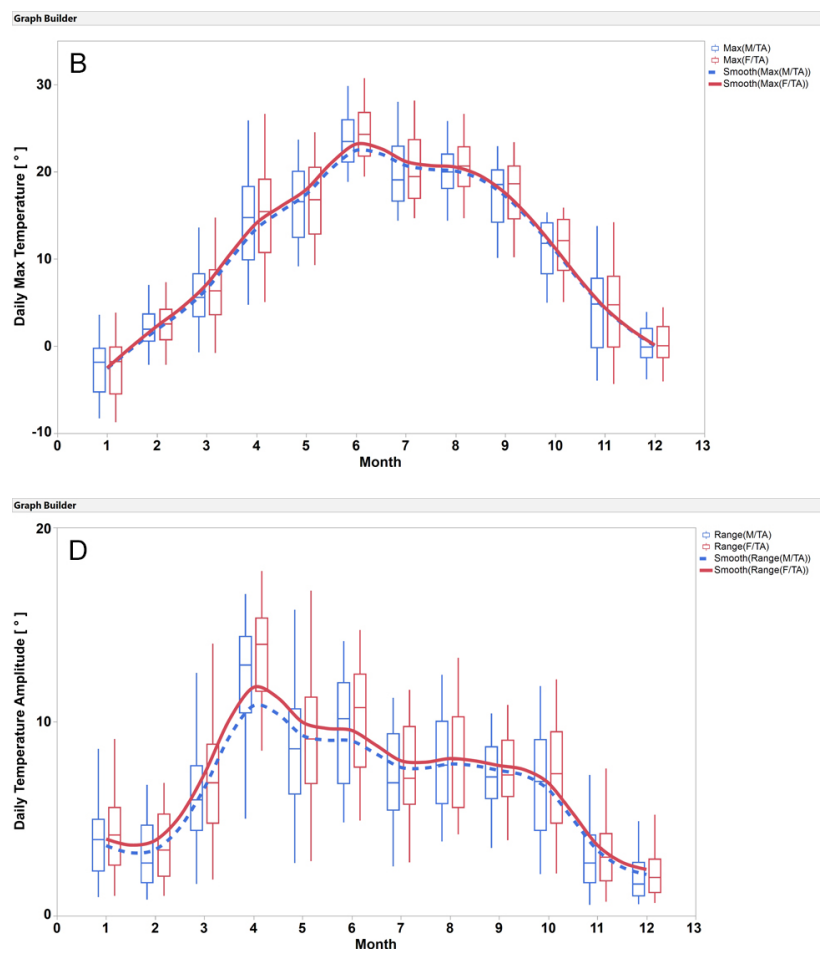

Ryc. 1. Zmienność temperatury na badanych stanowiskach A - minimalna temperatura dzienna, B - maksymalna temperatura dzienna, C - średnia temperatura dzienna, D - dzienna amplituda temperatury, E - mediana temperatury dziennej (kolor czerwony dane dla stanowisk z Frullania dilatata, niebieski - stanowiska bez tego gatunku)

Fig. 1. Temperature parameters at the tested localities A - daily minimum temperature, B - daily maximum temperature, $\mathrm{C}$ - daily mean temperature, $\mathrm{D}$ - daily temperature amplitude, $\mathrm{E}$ - daily median temperature (in red - data for sites with Frullania dilatata, in blue - sites without $F$. dilatata

Do modelu (por. ryc. 3) weszły trzy zmienne, a w jej wyniku $90 \%$ przypadków zostało poprawnie sklasyfikowanych. Są to: średnia temperatura czerwca, średnia wilgotność względna września oraz nasłonecznienie (ISF, indirect site factor). Z analizy wyraźnie wynika, że stanowiska Frullania + korespondują $z$ wysokimi wartościami średniej temperatury czerwca oraz średniej wilgotności względnej we wrześniu.

\section{DYSKUSJA}

Uzyskane wyniki analiz termicznych i wilgotnościowych wskazują, że temperatura i wilgotność w obrębie lasów Wigierskiego Parku Narodowego nie ma większego wpływu na rozmieszczenie epifitycznych wątrobowców, takich jak $F$. dilatata czy $M$. furcata. Trzeba także pamiętać, że mówimy o różnicowaniu tych czynników już w obrębie zwartego kompleksu leśnego. Nie należy tego wiązać $z$ faktem, iż generalnie występowanie epifitów i epiksyli w lasach jest warunkowane ich wysoką (w stosunku do terenów otwartych) wilgotnością oraz stabilniejszą 

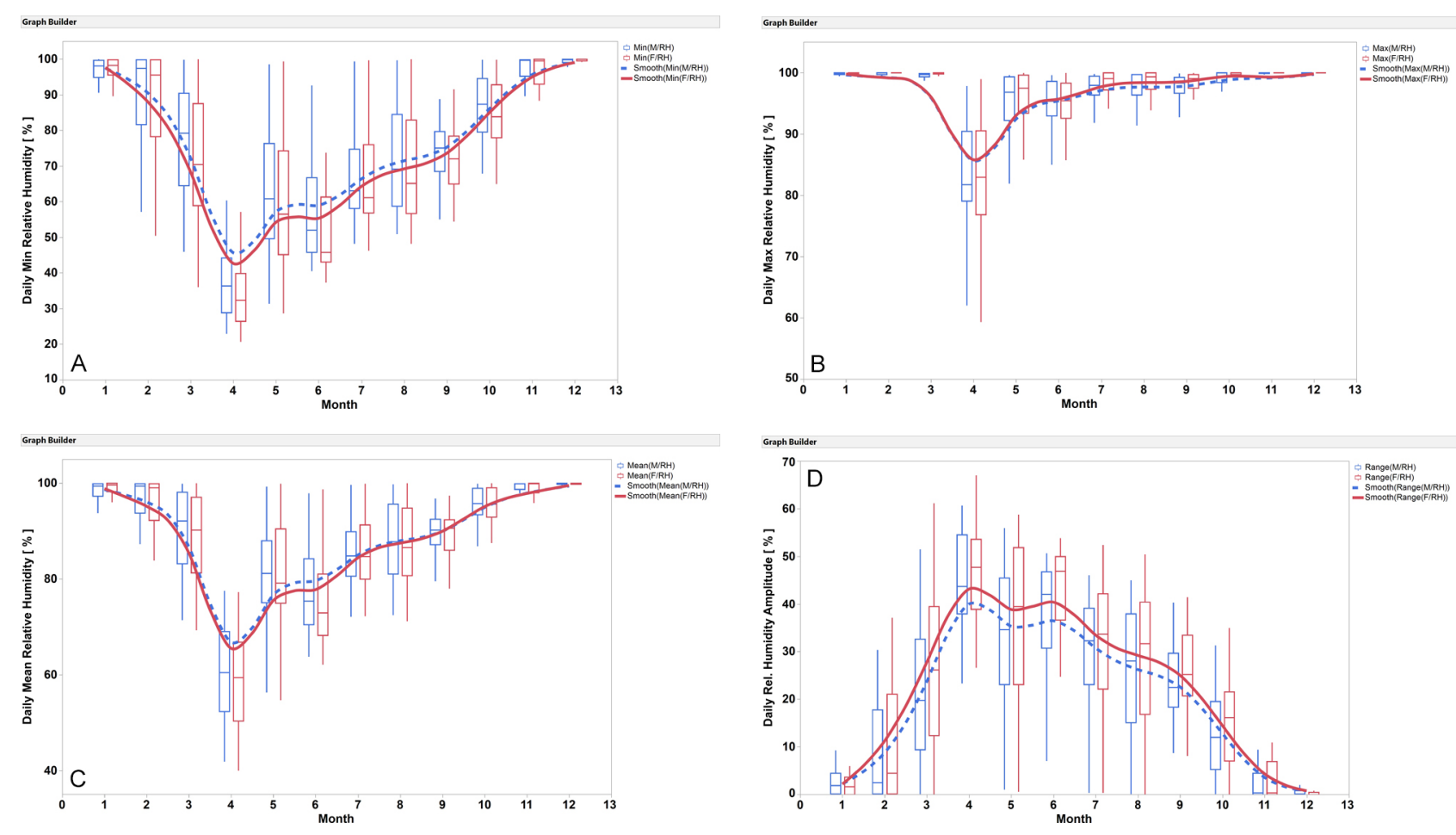

Ryc. 2. Zmienność wilgotności względnej na badanych stanowiskach

A - minimalna wilgotność względna dzienna, B - maksymalna wilgotność względna dzienna, C - średnia wilgotność względna dzienna, D - dzienna amplituda wilgotności względnej, E - mediana wilgotności względnej dziennej (kolor czerwony - dane dla stanowisk z Frullania dilatata, niebieski - stanowiska bez tego gatunku)

Fig. 2. Relative humidity at the tested localities

A - daily minimum relative humidity, B - daily maximum relative humidity, $\mathrm{C}$ - daily mean relative humidity, $\mathrm{D}$ - daily relative humidity amplitude, $\mathrm{E}$ - daily median relative humidity (in red - data for sites with Frullania dilatata, in blue - sites without F. dilatata)

temperaturą (SÖDERSTRÖM 1988, ANDERSSON \& HYTteborn 1991, Vellak \& PaAl 1999, Klama 2002). W wyniku prowadzonych wcześniej badań na terenie WPN nad rzadkim, epiksylicznym puszczańskim wątrobowcem Fuscocephaloziopsis catenulata (GórsKi i in. 2019) ustalono, że czynnikiem decydującym o jego występowaniu jest stabilność warunków termiczno-wilgotnościowych (niewielkie amplitudy dzienne). W odniesieniu do epifitycznego gatunku, jakim jest miedzik płaski (F. dilatata) jest wręcz odwrotnie. Mikrosiedliska tej rośliny cechują się większą niestabilnością zarówno temperatury, jak i wilgotności w porównaniu z pozostałymi epifitami, np. M. furcata. Wydaje się, że możliwość wegetacji w takich warunkach powinna być cennym przystosowaniem w sytuacjach zmian w zwarciu drzewostanu wywołanych gospodarką leśną lub czynnikami naturalnymi. $\mathrm{Z}$ tego powodu zmiany wilgotności i temperatury w obrębie ekosystemu leśnego nie tłumaczą rzadkości tej rośliny.

$\mathrm{Z}$ kolei analiza warunków nasłonecznienia daje zaskakujące wyniki. Powszechnie podkreślany jest

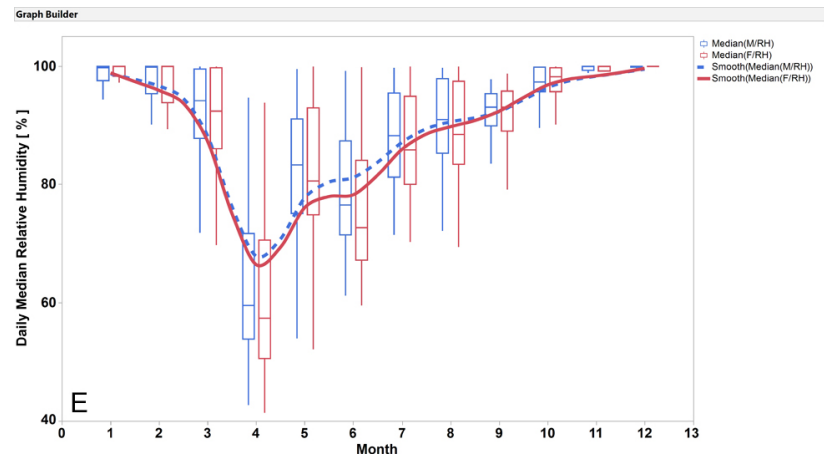

fakt częstego występowania $F$. dilatata w prześwietleniach drzewostanu, alejach drzew przydrożnych lub nawet pojedynczych drzewach poza zwartym lasem (np. Stebel \& Zubel 2018). Obraz rozmieszczenia tej rośliny w Wigierskim Parku Narodowym wskazuje, że przeciętnym siedliskiem $F$. dilatata nie są stanowiska nasłonecznione. To także podkreśla trafność wyboru powierzchni badawczych w niniejszych badaniach, bliższe zasadzie losowości niż doborowi miejsca $z$ założoną tezą. Możliwość występowania miedzika płaskiego na siedliskach mocno nasłonecznionych można tłumaczyć przystosowaniami tej rośliny do oszczędnej gospodarki wodą. Gatunek ten ma liście boczne podzielone, $\mathrm{z}$ płatem brzusznym (od strony kory forofita) w kształcie mieszka/dzbanuszka gromadzącego wodę. Poza tym obecność rzędu amfigastriów jest czynnikiem dodatkowo zatrzymującym wodę spływającą grawitacyjnie po pniu. Dodatkowo, opisywana strona brzuszna jest przykryta liśćmi bocznymi gęsto dachówkowato zachodzącymi na siebie i wypukłymi (z brzegami podwiniętymi ku korze drzewa). Te mechanizmy z całą pewnością zapewniają 
roślinie zaopatrzenie $\mathrm{w}$ wodę powstającą każdego dnia $z$ porannej rosy, nawet pomimo późniejszego wzrostu temperatury $\mathrm{w}$ ciągu dnia. Takie właściwości mogą być wytłumaczeniem jednego $z$ wyników analizy dyskryminacyjnej, wskazującym na zależność w występowaniu F. dilatata $z$ wysoką średnią temperaturą dzienną w czerwcu. Należy zauważyć, że miesiąc ten jest najcieplejszy w lasach WPN (por. ryc. 1A, B, C). Z całą pewnością plechowate i jednowarstwowe gametofory $M$. furcata trudniej znoszą takie warunki.

Kolejny wynik analizy dyskryminacyjnej wskazuje na wyraźnie istotną statystycznie zależność w występowaniu F. dilatata od średniej wilgotności względnej powietrza we wrześniu (por. ryc. 3). Interpretacja
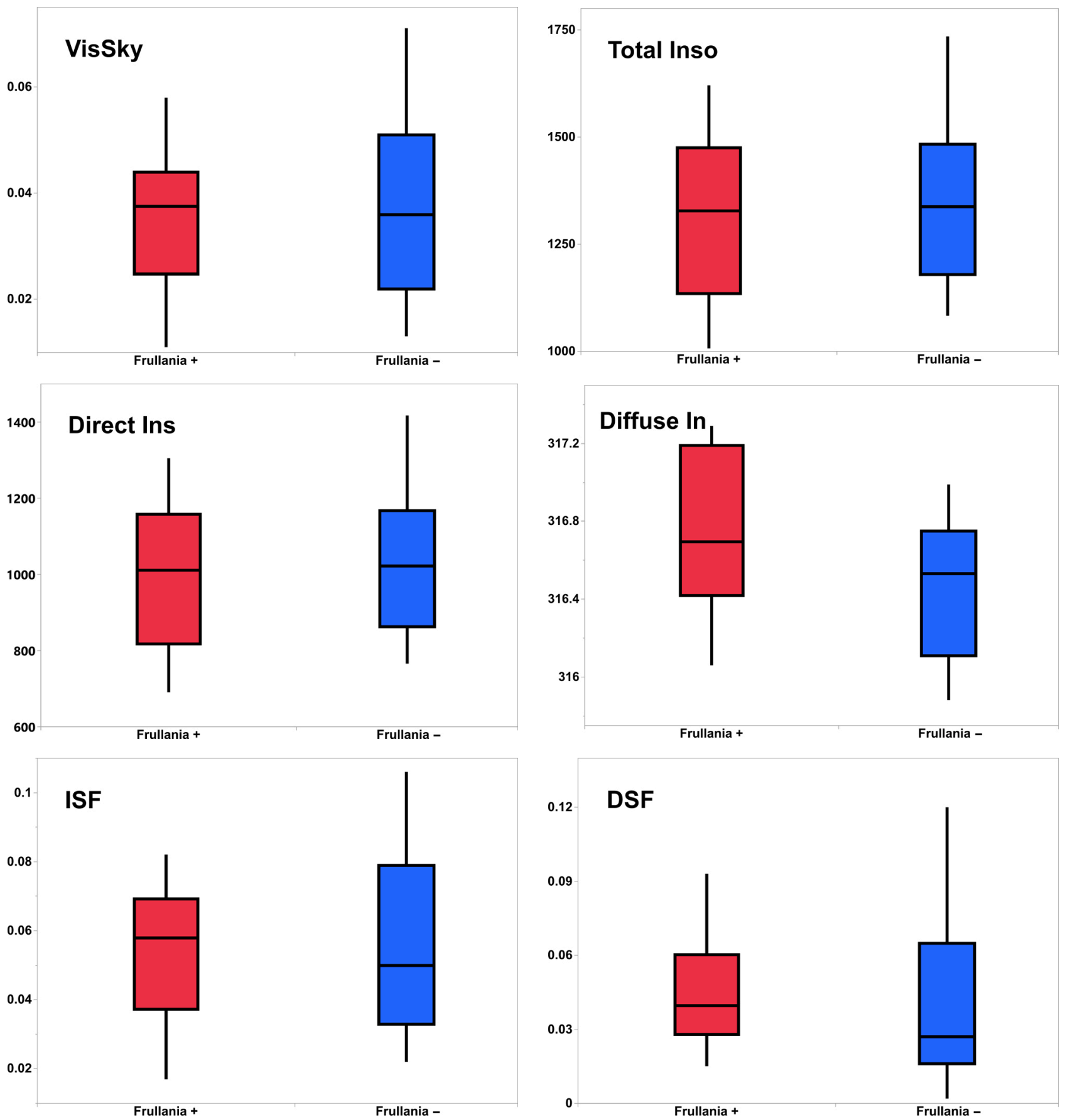

Ryc. 3. Wykresy pudełkowe dla porównania dwóch grup stanowisk (z Frullania i bez tego gatunku) pod względem warunków oświetlenia. Zastosowane testy wykazały, że obie grupy nie różnią się istotnie lub różnią się słabo (przy p $=0,05)$. Objaśnienia zmiennych: Diffuse In, Direct Ins, DSF, ISF, Total Inso, VisSky zobacz Materiał i metody

Fig. 3. Two groups of stands (with or without Frullania) were compared in terms of light conditions. Tests performed for these comparisons showed that the groups differ significantly only for Diffuse In $(a t p=0.05)$. Here, quantile box plots for two groups of stands are presented; for explanation of the variables Diffuse In, Direct Ins, DSF, ISF, Total Inso, VisSky see Material and methods 


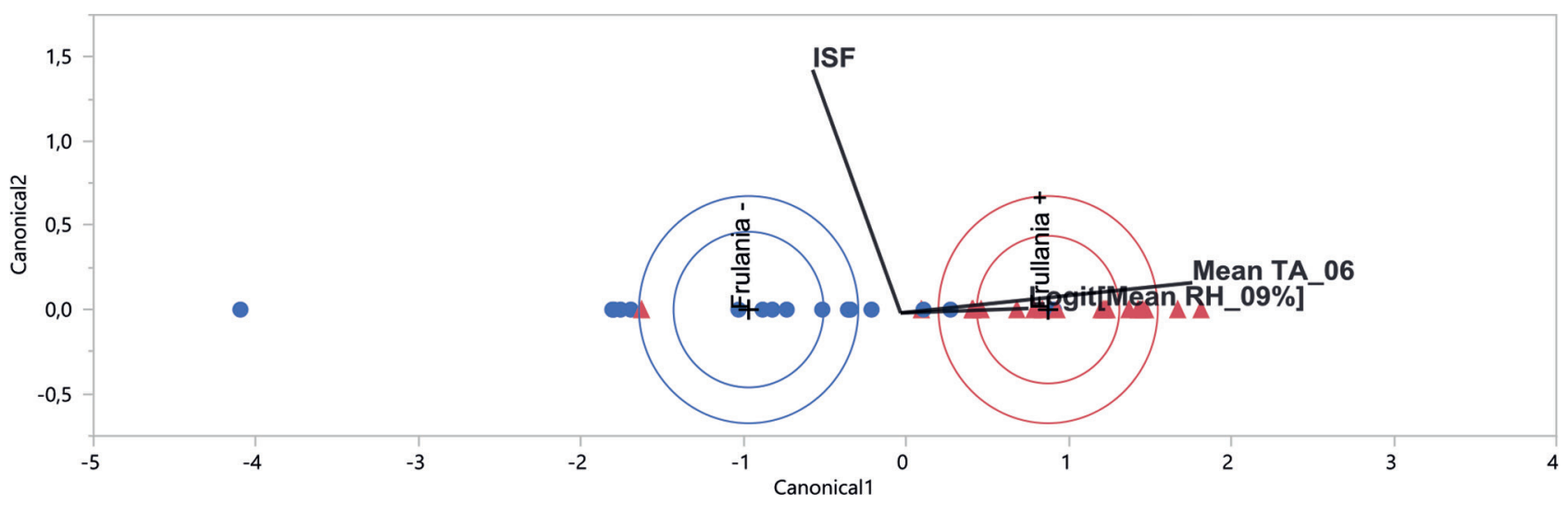

Ryc. 4. Wyniki analizy dyskryminacyjnej dla stanowisk z Frullania dilatata (Frullania +, 20 powierzchni) oraz bez tego gatunku (Frullania -, 18)

Objaśnienia: Mean TA_06 - średnia temperatura dzienna czerwca, Mean RH_09\% - średnia wilgotność względna dzienna września (\%), ISF - indirect site factor (zob. Materiał i metody).

Fig. 4. Linear Discriminant Analysis results for sites with or without Frullania dilatata

Abbreviations: Mean TA_06 - daily mean temperature in June, Mean RH_09\% - daily mean relative humidity in September (\%), ISF indirect site factor (see Material i methods).

tego zjawiska musi być ostrożna. Warto natomiast zwrócić uwagę na fakt, że wrzesień jest pierwszym miesiącem po upalnym lecie (por. ryc. 1 i 2), w którym niższa temperatura i ponownie wysoka wilgotność zapewniają korzystne warunki do rozmnażania generatywnego omawianego wątrobowca. Gatunek ten obficie tworzy tworzy peryancja. Sama obecność wymienionej struktury otaczającej rodnie jest dla F. dilatata kolejną korzyścią (poza rekombinacją materiału genetycznego) polegającą na możliwości wegetatywnego rozmnażania poprzez rozmnóżki tworzące się na peryancjum. U tego gatunku mamy wyjątkową sytuację, że rozmnóżki bardzo rzadko tworzą się na liściach gametoforu (co jest powszechne u innych wątrobowców, rzadsze u mchów), a wykształcają się na peryancjach. Im dłuższy będzie okres korzystny dla rozmnażania płciowego, tym bardziej zwiększy się możliwość wegetatywnej propagacji. Ten okres rozpoczyna się najwcześniej we wrześniu i może trwać $\mathrm{w}$ październiku i listopadzie. Takich zależności nie można przypisać $M$. furcata (główny komponent grupy Frullania -). Wątrobowiec ten przez cały sezon wegetacyjny obficie tworzy wielokomórkowe rozmnóżki na brzegu plechy, rzadko tworzy organy płciowe.

Podsumowując, należy podkreślić, że celem strategicznym prowadzonych badań było określenie, czy wilgotność i temperatura (przy istotnym wpływie oświetlenia) są najważniejszymi elementami warunkującymi występowanie $F$. dilatata w ekosystemach leśnych. Realizacja tego projektu daje odpowiedź na to pytanie. Wymienione czynniki nie mają strategicznego znaczenia w odniesieniu do lasów Wigierskiego Parku Narodowego. Nie można zatem wyjaśnić rzadkości występowania tej rośliny w kontekście pogarszania się ( $z$ punktu widzenia wegetacji gatunku) wilgotności czy temperatury (mikroklimatu) wnętrza lasu. Badania wyraźnie wskazują, że można próbować powiązać zmienność tych czynników w sezonie wegetacyjnym z pewnymi właściwościami biologicznymi gatunku.

\section{PODZIĘKOWANIA}

Badania dofinansowano ze środków funduszu leśnego, w ramach umowy zawartej pomiędzy Państwowym Gospodarstwem Leśnym Lasy Państwowe a Wigierskim Parkiem Narodowym (EZ.0290.1.20.2019 - Działanie nr 40).

\section{LITERATURA}

Andersson L.I., Hytteborn H. (1991): Bryophytes and decaying wood: A comparison between managed and natural forest. Holarctic Ecology 14: 121-130.

Boehner J., Antonic O. (2009): Land-surface parameters specific to Topo-Climatology. W: T. Hengl, H. Reuter (red.). Geomorphometry - Concepts, Software, Applications. Developments in Soil Science 33: 195-226.

Fojcik B., Zubel R., Wierzcholska S., Rosadziński S., Staniaszek-Kik M., RusińsKa A., Szczepański M., Vončina G., Wolski G., Ciurzycki W., Górski P., Piwowarski B., Pawlikowski P. (2017): Materiały do brioflory rezerwatu przyrody Boczki (Puszcza Romincka). Steciana 21(4): 147-158.

FudAli E. (1999): Mszaki rezerwatów leśnych Puszczy Bukowej pod Szczecinem na tle zróżnicowania fitosocjologicznego i ekologicznego siedlisk. Badania Fizjograficzne nad Polską Zachodnią, Seria B, Botanika 48: 165-187.

GocŁawsKa D. (1966): Materiały do flory mszaków Puszczy Knyszyńskiej. Cz. 1. Mszaki nadleśnictwa Złota Wieś. Fragmenta Floristica et Geobotanica 12(2): 185-193. 
GóRSKI P. (2006a): Liverworts of the nature reserve in Wielkopolska. 1. "Las Łęgowy w Dolinie Pomianki”. Roczniki Akademii Rolniczej w Poznaniu 378, Botanika-Steciana 10: 87-96.

GóRSKI P. (2006b): Liverworts of the nature reserve in Wielkopolska. 2. "Olbina". Roczniki Akademii Rolniczej w Poznaniu 378, Botanika-Steciana 10: 97-102.

GóRsKI P. (2006c): Liverworts of the nature reserve in Wielkopolska. 3. "Dąbrowa koło Biadek Krotoszyńskich”. Roczniki Akademii Rolniczej w Poznaniu 378, Botanika-Steciana 10: 103-108.

GóRSKI P. (2007a): Liverworts of the nature reserve in Wielkopolska Region. 4. "Dolina Kamionki". Roczniki Akademii Rolniczej w Poznaniu 386, Botanika-Steciana 11: 73-76.

GóRSKI P. (2007b): Liverworts of the nature reserve in Wielkopolska Region. 5. "Uroczysko Jary". Roczniki Akademii Rolniczej w Poznaniu 386, Botanika-Steciana 11: 77-79.

GóRSKI P. (2007c): Liverworts of the nature reserve in Wielkopolska Region. 6. "Kozie Brody", "Wilcze Błoto", "Jezioro Czarne" and "Brzeziny". Roczniki Akademii Rolniczej w Poznaniu 386, Botanika-Steciana 11: 81-84.

GóRSKI P. (2010): A contribution to the liverwort flora of the Drawsko Lake district (Western Pomerania, Poland). Roczniki Akademii Rolniczej w Poznaniu 389, Botanika-Steciana 14: 19-26.

GóRSKI P. (2013): Wątrobowce (Marchantiophyta) Leśnego Kompleksu Promocyjnego „Lasy Środkowopomorskie" (Pomorze Zachodnie). PGL Lasy Państwowe Nadleśnictwo Karnieszewice, Wydawnictwo Uniwersytetu Przyrodniczego w Poznaniu, Sianów-Poznań.

GóRski P., Romański M. (2018): Wątrobowiec Frullania dilatata $\mathrm{w}$ Wigierskim Parku Narodowym na tle jego występowania w Polsce. Steciana 22(3): 101-114.

GóRsKi P., RomańsKi M., ToMAszeWSKI D. (2019): Seeking for habitat characteristics which determine epixylic liverwort Fuscocephaloziopsis catenulata occurrence in old boreal forests in north-eastern Poland. Herzogia 32: 172-182.

Hantzschel J., Goldberg V., Bernhofer C. (2005): GIS-based regionalisation of radiation, temperature and coupling measures in complex terrain for low mountain ranges. Meteorological Applications 12:01: 33-42.

Hodgetts N.G. (2015): Checklist and country status of European bryophytes - towards a new Red List for Europe. Irish Wildlife Manuals, No. 84. National Parks and Wildlife Service, Department of Arts, Heritage and the Gaeltacht, Ireland.

Karczmarz K., Sokołowski A.W. (1992): Brioflora Puszczy Knyszyńskiej. Annales Universitatis Mariae Curie-Skłodowska, Sectio C, Biologia 47: 89-118.
Karczmarz K., SokoŁowski A.W. (1995): Mchy i wątrobowce Puszczy Knyszyńskiej. W: A. Czerwiński (red.). Puszcza Knyszyńska. Monografia Przyrodnicza. Zespół Parków Krajobrazowych w Supraślu, Supraśl: 155-171.

Klama H. (2002): Distribution patterns of liverworts (Marchantiopsida) in natural forest communities (Białowieża Primeval Forest, NE Poland). University of Bielsko-Biała, Bielsko-Biała.

Klama H., Górski P. (2018): Red List of Liverworts and Hornworts of Poland (4th edition, 2018). Cryptogamie, Bryologie 39(4): 415-441.

KubinskÁ A., Janovicová K., Šoltés R. (2001): Aktualizovaný zoznam pečeňoviek, rožtekov a machov Slovenska. Bryonora 28: 4-10.

KuČERA J., VÁŇA J., Hradílek Z. (2012): Bryophyte flora of the Czech Republic: updated checklist and Red List and a brief analysis. Preslia 84: 813-850.

ŁaCHACZ A., PisareK W. (2007): Flora mszaków i roślin naczyniowych rezerwatu przyrody Małga na Równinie Mazurskiej. Parki Narodowe i Rezerwaty Przyrody 26(2): 17-28.

MierzeńsKa M. (1994): Wątrobowce Gorców. Fragmenta Floristica et Geobotanica - Series Polonica 1: 235-346

OKE T.R. (2000): Boundary layer climates. Taylor \& Francis, New York.

Pisarek W., Sawicki J., Szczecińska M. (2002): Flora roślin naczyniowych i mszaków rezerwatu „Źródła rzeki Łyny im. prof. R. Kobendzy”. Acta Botanica Warmiae et Masuriae 2: 93-110

Rejment-Grochowska I. (1964a): Materiały do flory mszaków Mazowsza. Dolina Bugu na odcinku Serock-Zegrze. Fragmenta Floristica et Geobotanica 7(1): 169-178.

Rejment-Grochowska I. (1964b): Materiały do flory mszaków Mazowsza z powiatu Pułtusk i parku w Jabłonnie. Fragmenta Floristica et Geobotanica 10(2): 239--247.

Rejment-Grochowska I., Mickiewicz J. (1962): Materiały do flory mszaków Suwalszczyzny. Fragmenta Floristica et Geobotanica 8(1): 3-22.

Schnyder N., Bergamini A., Hofmann H., Müller N., Schubiger-Bossard C., Urmi E. (2004): Rote Liste der gefährdeten Arten der Schweiz. Moose. BUWAL, FUB \& NISM. BUWAL-Reihe, Vollzug Umwelt.

SöDERström L. (1988): The occurrence of epixylic bryophyte and lichen species in an old natural and a managed forest stand in northeast Sweden. Biological Conservation 45: 169-178.

Stebel A. (1997): Mszaki okolic Węgorzewa na Pojezierzu Mazurskim. Fragmenta Floristica et Geobotanica Series Polonica 4: 235-244.

Stebel A. (2002): Materiały do brioflory Parku Narodowego Bory Tucholskie (Pomorze Zachodnie). Parki Narodowe i Rezerwaty Przyrody 21(2): 159-175 
Stebel A. (2008): Materiały do rozmieszczenia chronionych i rzadkich gatunków mszaków na Śląsku Opolskim. Natura Silesiae Superioris 11: 11-25

Stebel A. (2012): Preliminary studies on the bryoflora of the Narwiański National Park (NE Poland). Časopis Slezského Muzea, Series A, Opava 61: 265-271.

Stebel A., Zubel R. (2018): Wątrobowiec Frullania dilatata (Jubulaceae) w polskiej części Karpat rozmieszczenie, ekologia, zagrożenia. Roczniki Bieszczadzkie 26: 151-168.

SzWEYKOWSKI J. (2006): An annotated checklist of Polish liverworts and hornworts. - Krytyczna lista wątrobowców i glewików Polski. Biodiversity of Poland. Vol. 4. W. Szafer Institute of Botany, Polish Academy of Sciences, Kraków.

Vellak K., PaAl J. (1999): Diversity of bryophyte vegetation in some forest types in Estonia: a com- parison of old unmanaged and managed forests. Biological Conservation 8: 1595-1620.

WiLCZYŃSKA W. (1974): Flora mchów i zbiorowisk mszaków Gór Kaczawskich. Studium florystyczno-ekologiczne. Monographiae Botanice 44: 3-111.

Wilson J.P., Gallant J.C. (2000): Secondary topographic attributes. W: J.P. Wilson, J.C. Gallant (red.). Terrain analysis: Principles and applications. John Wiley \& Sons Inc., New York: 87-131.

For citation: GóRsKI P., RoMAŃsKI M., TOMASZEWSKI D. (2019): Siedliskowe uwarunkowania występowania wątrobowca Frullania dilatata w Wigierskim Parku Narodowym (północno-wschodnia Polska). Steciana 23, 4: 41-49. doi: 10.12657/steciana.023.004 